\section{Growth of Containerized Atlantic White Cedar Seedlings as Affected by Container Volume, Substrate, Fertilizer, and Irrigation}

\author{
Scott A. Derby ${ }^{1}$ and L. Eric Hinesley ${ }^{2}$ \\ Department of Horticultural Science, North Carolina State University, Raleigh, \\ NC 27695-7609
}

Additional index words. Chamaecyparis thyoides, irrigation, wetlands restoration, controlled-release fertilizer, germination

\begin{abstract}
Germination and growth of atlantic white cedar [Chamaecyparis thyoides (L.) B.S.P.] was evaluated in response to four container volumes $\left(98\right.$ to $\left.530 \mathrm{~cm}^{3}\right)$, two substrates [North Carolina Forest Service (NCFS) container mix [ 3 canadian peat : 2 coarse vermiculite : 1.5 perlite (by volume), and 3 composted pine bark : 1 peat (by volume)], two controlled-release fertilizers [Osmocote $15 \mathrm{~N}-4.0 \mathrm{P}-10.0 \mathrm{~K}\left(15 \mathrm{~N}-9 \mathrm{P}_{2} \mathrm{O}_{5}-12 \mathrm{~K} O\right)$, 12- to 14-month southern formulation, with micros; and Polyon 18N-2.6P-10.0K $\left(18 \mathrm{~N}-6 \mathrm{P}_{2} \mathrm{O}_{5}-12 \mathrm{~K}_{2} \mathrm{O}\right)$ with micros, 9-month formulation], and three irrigation frequencies $(2,3$, or 4 times daily). Although growth increased up to the maximum container volume $\left(530 \mathrm{~cm}^{3}\right)$, the optimum for 1-yearold seedlings appeared to be 164 to $262 \mathrm{~cm}^{3}$. The higher peat content and water holding capacity of the NCFS substrate yielded better growth than 3 bark: 1 peat. Osmocote yielded larger and heavier plants than Polyon, probably owing to more available phosphorus in the former. Irrigation three times daily was optimum. Suitable manipulation of container volume, substrate, fertilizer, and irrigation should yield high quality containerized atlantic white cedar seedlings.
\end{abstract}

Atlantic white cedar [Chamaecyparis thyoides (L.) B.S.P] (AWC) is an evergreen wetland tree native to fresh water swamps and bogs along a narrow coastal belt from southern Maine to northern Florida, and western to southern Mississippi (Korstian and Brush, 1931; Laderman, 1989). Historically, AWC was quite valuable for its lightweight, decay resistant wood (Krinbill, 1956; Ward, 1989), and more recently has found limited use as an ornamental (Dirr, 1990). The largest assemblage of AWC was originally in the Great Dismal Swamp bordering North Carolina and Virginia (Ashe, 1894). Since the late 1800s, natural stands have dwindled due to drainage of peat lands for agriculture, logging without subsequent regeneration, and wildfires (Bentz and Iverson, 1992; Frost, 1987; Korstian and Brush, 1931; Lilly, 1981; Ward, 1989). Today, AWC occupies only a small fraction of its original area (Davis et al., 1997; Kuser and Zimmerman, 1995; Phillips et al., 1998)

\footnotetext{
Received for publication 16 Dec. 2004. Accepted for publication 22 May 2005. This research was funded in part by the North Carolina Agricultural Research Service (NCARS), Raleigh, NC 276957643 and by a grant from the U.S. Fish and Wildlife Service, Arlington, VA 22203. We thank Greg Pate, Bobby Smith, Selby Hawk, and other N.C. Forest Service personnel for assistance in this research. Ted Bilderback and Mary Lorsheider kindly performed substrate analysis. This paper is part of a MS thesis by the senior author. Use of trade names does not imply endorsement by the NCARS or USFWS of products named, nor criticism of similar ones not mentioned.

${ }^{1}$ Research technician.

${ }^{2}$ Professor.
}

Despite strong interest in restoring AWC to former sites (Hinesley and Wicker, 2003; Kuser and Zimmerman, 1995; Phillips et al. 1998), efforts have yielded limited success, partly due to a lack of quality planting stock. Atlantic white cedar can be propagated from stem cuttings (Boyle and Kuser, 1994; Hinesley and Snelling, 1997), but costs are higher than seedlings. Production of seedlings in outdoor nursery beds has been inconsistent owing to low utilization efficiency of seed and inadequate control of bed density (Bianchetti et al., 1994; Summerville et al., 1999). Current efforts by the North Carolina Forest Service (NCFS) are focused on production of containerized seedlings. The objective of this research was to examine the growth of AWC seedlings in response to container size, substrate, fertilizer, and irrigation.

\section{Methods and Materials}

On 29 Apr. through 2 May 2002, seeds of AWC were hand-sown into four types of containers at the NCFS nursery in Goldsboro. Containers were Ropak Multi-pots (45 cells/ tray, volume $\left.=98 \mathrm{~cm}^{3}\right)$, Ray Leach Cone-tainer Super Cells $\left(98\right.$ cells/tray, volume $\left.=164 \mathrm{~cm}^{3}\right)$, Ray Leach Deepots (D16 size, 50 cells/tray, volume $\left.=262 \mathrm{~cm}^{3}\right)$, and HIKO trays (V-530 model, 15 cells/tray, volume $=530 \mathrm{~cm}^{3}$ ) (Stuewe \& Sons, Inc., Corvallis, Ore.).

Containers were filled with factorial combinations of two substrates amended with two types of controlled-release fertilizer(CRF). The two substrates were either the standard NCFS container mix consisting of 3 Canadian peat : 2 coarse vermiculite : 1.5 perlite (by volume), or 1 composted pine bark: 1 peat (by volume). Fertilizers were Osmocote $15 \mathrm{~N}-4.0 \mathrm{P}-10.0 \mathrm{~K}$ $\left(15 \mathrm{~N}-9 \mathrm{P}_{2} \mathrm{O}_{5}-12 \mathrm{~K}_{2} \mathrm{O}\right), 12$ to 14 month southern formulation, with micros (Scotts-Sierra Horticultural Products Co., Marysville, Ohio); and Polyon $18 \mathrm{~N}-2.6 \mathrm{P}-10.0 \mathrm{~K}\left(18 \mathrm{~N}-6 \mathrm{P}_{2} \mathrm{O}_{5}-\right.$ $12 \mathrm{~K}_{2} \mathrm{O}$ ) with micros, 9-month formulation (Pursell Technologies Inc., Sylacauga, Ala.). Both fertilizers were incorporated at $6.9 \mathrm{~kg} \cdot \mathrm{m}^{-3}$. The number of cells planted in each type of tray was as follows: Ropaks (45), Super Cells (49), Deepots (35), and HIKO (30 cells; two trays, side-by-side). Two to five seeds were dropped in each cell to ensure that a high percentage of cells would be occupied after seed germination. Trays were top dressed with a thin layer of fine vermiculite, and watered immediately with a mist nozzle before placement outdoors.

The experimental design was a split plot with six replications, three irrigation schedules, and 16 subplot treatments, totaling 288 plots and 11,448 cells. Irrigation regimes comprised main plots, and the 16 subplot treatments consisted of factorial combinations of four containers, two substrates, and two sources of CRF.

In the nursery, each main plot consisted of two wooden pallets placed side by side with an $45-\mathrm{cm}$ irrigation riser in the center. Nozzles were individual Roberts spot spinners $[\# 7305=$ green $=1.1 \mathrm{~L} \cdot \mathrm{min}^{-1}$ at $\left.20 \mathrm{psi}(0.14 \mathrm{MPa})\right]$. The main plots - about $2 \mathrm{~m}$ apart-were arranged in two parallel rows, with each row covered by $50 \%$ shade cloth. Incoming water lines were also covered with shade. Trays were placed on wooden pallets, and subjected to $15 \mathrm{~min} \cdot \mathrm{h}^{-1}$ of overhead irrigation from 8 AM until 7 PM during the germination period. Germination was evaluated after 2 months ( 2 and 3 July) by counting the number of occupied cells in each tray.

On 9 July 2002, seedlings were thinned to one plant per cell, and the three irrigation treatments were initiated, consisting of $15 \mathrm{~min}$ of overhead irrigation $2 \times, 3 \times$, or $4 \times$ daily. All watering schedules spanned $9 \mathrm{~h}$ from initial to final watering, beginning around $7 \mathrm{AM}$, and were regulated by clocks and solenoids. Vertical plastic dividers were installed between plots to isolate irrigation treatments.

To evaluate growth, a sample of seedlings was taken from each plot on 30 and 31 Oct. 2002. Nine plants were selected systematically, using a grid pattern which omitted border rows. If a target cell was empty, the next closest plant was chosen. Plants were shaken of substrate, placed in plastic bags, returned to Raleigh, and stored at $-2{ }^{\circ} \mathrm{C}$ until processing. After washing roots free of substrate, height was measured (to $0.5 \mathrm{~cm}$ ) with a ruler, and stem diameter near the base was measured in two directions (to $0.01 \mathrm{~mm}$ ) using digital calipers. The five plants closest to the plot average height and stem diameter were selected for dry weight determination. These plants were washed of substrate, divided into root and shoot components, dried to constant weight at $65^{\circ} \mathrm{C}$, and root and shoot dry weights (g) measured. Foliage from four replications was chemically analyzed by the Agronomic Division of the North Carolina Dept. of Agriculture and Consumer Protection, 


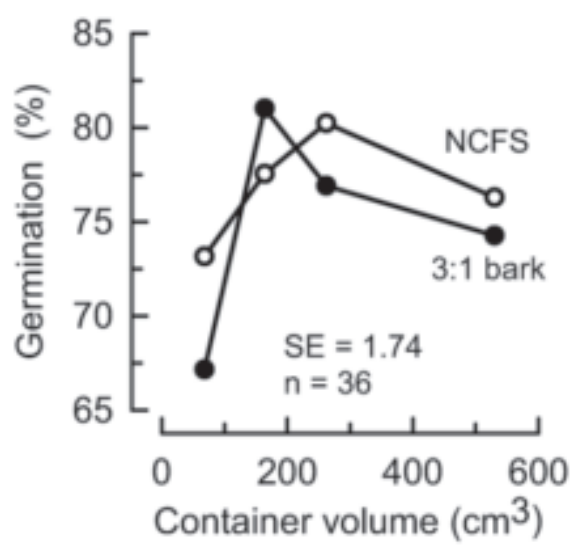

Fig. 1. Seed germination of atlantic white cedar in response to container volume and substrate. Values represent the percent of planted cells that were occupied by at least one seedling after a 2 -month germination period. (-) 3 bark: 1 peat substrate, (O) NCFS substrate. $\mathrm{SE}=$ standard error of the mean; $\mathrm{n}=$ observations in each mean.

using standard procedures (Campbell, 1992; Campbell and Plank, 1992).

Based on an examination of residuals and variances, data for dry weight (shoot, roots, total) were converted with a square-root transformation before analysis. Other variables were analyzed in original units. Data were analyzed using general linear model (GLM) procedures (SAS Institute, 1990). Water regimes and container types were compared with 1-df contrasts.

\section{Results}

Germination (cell occupancy) in the Super Cell and Deepot containers averaged $79 \%$, while Ropaks yielded 70\% (Fig. 1). Maximum germination $(81 \%)$ occurred in the 3 bark : 1 peat medium (Super Cell), though the NCFS substrate yielded higher germination in all other container volumes, especially in Ropaks. The lowest cell occupancy (64\%) was in Ropaks with 3 bark : 1 peat substrate.

Stepping up to a larger container always significantly increased plant dry weight (Table 1, Fig. 2); the most notable change occurred when volume went from $98 \mathrm{~cm}^{3}$ (Ropaks) to $164 \mathrm{~cm}^{3}$ (Super Cells). Additional increases in volume were accompanied by a linear increase in plant height and dry weight. The most uniform plants, for both substrates and CRFs, grew in Super Cells $\left(164 \mathrm{~cm}^{3}\right)$ and Deepots $\left(262 \mathrm{~cm}^{3}\right)$.

Height and stem diameter were affected by all variables except irrigation regime (Table 1). Maximum height was $32 \mathrm{~cm}$ (V530 tray, Osmocote, NCFS substrate); the minimum $12 \mathrm{~cm}$ (Ropaks, Polyon, bark substrate). The container $\times$ fertilizer interaction was most evident in Super Cells, as Osmocote plants were $30 \%$ taller than Polyon plants ( 26 vs. 20 $\mathrm{cm}$ ) (Fig. 2A). Stem diameters were largest for the NCFS substrate amended with Osmocote (Fig. 2B). Average maximum and minimum diameter was $3.7 \mathrm{~mm}$ (V530 tray, NCFS mix, Osmocote) and $1.6 \mathrm{~mm}$ (Ropaks, bark mix, Polyon), respectively.

Osmocote treatments yielded larger plants than Polyon, with only one exception (V530 trays, bark substrate) (Fig. 2), and differences were most evident for root dry weight (Fig. 2C). In addition, the NCFS substrate yielded larger plants than the bark substrate, with the difference most evident in the larger containers (V530 and Deepot) (Fig. 2). In general, the tallest and heaviest plants were in the NCFS substrate amended with Osmocote; the smallest in the bark substrate amended with Polyon.

Irrigation frequency affected shoot dry weight and total dry weight (Table 1). The NCFS substrate and Osmocote yielded the heaviest plants for irrigation frequencies of $2 x$ and $3 \times$ daily (Fig. 3 ); the smallest plants were in the bark mix and Polyon. Increasing irrigation frequency from $2 \times$ to $3 \times$ daily increased total dry weight by an average of $12 \%$. However, irrigating $4 \times$ daily did not increase dry weight for any treatments except the Osmocote and NCFS substrate, where maximum root and shoot dry weight was $32 \%$ to $75 \%$ and $44 \%$ to $55 \%$ greater, respectively, than other treatments at the same irrigation frequency (Fig. 3A).

All macro- and micronutrients showed one or more significant main effects and/or interactions (Table 1). Nitrogen was highest at $3 \times$ irrigation frequency (Fig. 4A), increased with container volume (Fig. 4B), and was highest in Polyon treatments (Fig. 4C). Phosphorus increased with increasing peat content (Fig. 4D) and container volume (Fig. 4E), and $P$ levels in Osmocote treatments were almost $2 \times$ those in Polyon treatments (Fig. 4E). Foliar $\mathrm{K}$ ranged from $0.78 \%$ to $0.92 \%$, with no clear pattern related to treatments (data not shown). Calcium concentrations were highest for treatments involving Osmocote and/or the bark substrate (Fig. 4F). Magnesium was highest for the NCFS substrate and/or Osmocote treatments (Fig. 4G). Sulfur was lowest in Ropaks, and highest for Polyon treatments (range: $0.07 \%$ to $0.10 \%$ ) (Fig. $4 \mathrm{H}$ ). Foliar iron increased slightly with container volume, and in general, was relatively high for all treatments $($ Osmocote $=424 \mathrm{ppm}$; Polyon $=380 \mathrm{ppm})$ (Fig. 4I). Manganese increased with container volume (Fig. 4J), and values were almost $3 \times$ higher $(592 \mathrm{ppm})$ for the bark substrate than the NCFS mix (202 ppm)(Fig. 4K). Zinc was lowest in Ropaks, and highest for the bark substrate (Fig. 4L). Copper was lowest in

Table 1. Statistical analysis for growth and foliar mineral nutrient concentrations in seedlings of atlantic white cedar grown with varying irrigation frequencies, container volumes, fertilizer sources, and container substrates.

\begin{tabular}{|c|c|c|c|c|c|c|c|c|c|c|c|c|c|c|c|c|c|}
\hline \multirow[b]{2}{*}{ Source $^{z}$} & \multirow[b]{2}{*}{$\mathrm{df}$} & \multirow[b]{2}{*}{$\mathrm{Ht}$} & \multirow{2}{*}{$\begin{array}{l}\text { Stem } \\
\text { diam }\end{array}$} & \multirow{2}{*}{$\begin{array}{c}\text { Root } \\
\text { wt }^{\mathrm{y}}\end{array}$} & \multirow{2}{*}{$\begin{array}{c}\text { Shoot } \\
w^{y}\end{array}$} & \multirow{2}{*}{$\begin{array}{c}\text { Total } \\
w^{t^{y}}\end{array}$} & \multicolumn{11}{|c|}{ Mineral nutrient } \\
\hline & & & & & & & $\mathrm{N}$ & $\mathrm{P}$ & $\mathrm{K}$ & $\mathrm{Ca}$ & $\mathrm{Mg}$ & $\mathrm{S}$ & $\mathrm{Fe}$ & $\mathrm{Mn}$ & $\mathrm{Zn}$ & $\mathrm{Cu}$ & $\mathrm{B}$ \\
\hline Replication & 5 & --- & --- & --- & --- & --- & --- & --- & --- & --- & --- & --- & --- & --- & --- & --- & --- \\
\hline Irrigation $=\mathrm{I}$ & 2 & NS & NS & NS & $*$ & $*$ & $* *$ & $* *$ & NS & NS & NS & $* *$ & NS & $*$ & NS & NS & NS \\
\hline $2 \times$ vs. $3 \times$ & 1 & --- & --- & --- & $*$ & NS & $* *$ & $* *$ & --- & --- & --- & $* *$ & --- & NS & --- & --- & --- \\
\hline $3 \times$ vs. $4 \times$ & 1 & --- & --- & --- & NS & NS & NS & NS & --- & --- & --- & NS & --- & NS & --- & --- & --- \\
\hline Error a & 10 & --- & --- & --- & --- & --- & --- & --- & --- & --- & --- & --- & --- & --- & --- & --- & --- \\
\hline Volume $=\mathrm{V}$ & 3 & $* *$ & $* *$ & $* *$ & $* *$ & $* *$ & $* *$ & $* *$ & $* *$ & $* *$ & NS & $* *$ & $* *$ & $* *$ & $* *$ & $* *$ & NS \\
\hline V1 vs. V2 & 1 & $* *$ & $* *$ & $* *$ & $* *$ & $* *$ & $* *$ & $* *$ & NS & $* *$ & --- & $* *$ & $* *$ & $* *$ & $* *$ & $* *$ & --- \\
\hline V2 vs. V3 & 1 & $* *$ & $* *$ & $* *$ & $* *$ & $* *$ & $* *$ & $* *$ & $* *$ & $* *$ & --- & $* *$ & $*$ & $* *$ & $* *$ & $* *$ & --- \\
\hline V3 vs. V4 & 1 & $* *$ & $* *$ & $* *$ & $* *$ & $* *$ & $* *$ & $* *$ & $* *$ & $* *$ & --- & NS & NS & $* *$ & $*$ & NS & --- \\
\hline Fertilizer $=\mathrm{F}$ & 1 & $* *$ & $* *$ & $* *$ & $* *$ & $* *$ & $* *$ & $* *$ & NS & $* *$ & $* *$ & $* *$ & $* *$ & $*$ & $* *$ & $* *$ & $* *$ \\
\hline $\mathrm{V} \times \mathrm{F}$ & 3 & $*$ & NS & NS & NS & NS & NS & $* *$ & NS & $* *$ & NS & NS & NS & NS & $* *$ & NS & NS \\
\hline Substrate $=\mathrm{S}$ & 1 & $* *$ & $* *$ & $* *$ & $* *$ & $* *$ & $*$ & $* *$ & $* *$ & $* *$ & $* *$ & NS & NS & $* *$ & $* *$ & NS & $* *$ \\
\hline $\mathrm{V} \times \mathrm{S}$ & 3 & $*$ & $* *$ & NS & $* *$ & $* *$ & NS & NS & $*$ & NS & NS & NS & NS & $* *$ & $* *$ & NS & NS \\
\hline $\mathrm{F} \times \mathrm{S}$ & 1 & NS & NS & NS & NS & NS & $*$ & NS & $*$ & $* *$ & $* *$ & NS & NS & $*$ & $* *$ & NS & $*$ \\
\hline $\mathrm{V} \times \mathrm{F} \times \mathrm{S}$ & 3 & NS & NS & NS & NS & NS & NS & NS & NS & NS & NS & NS & NS & NS & NS & NS & NS \\
\hline $\mathrm{I} \times \mathrm{V}$ & 6 & NS & NS & NS & NS & NS & NS & NS & $* *$ & $*$ & NS & NS & NS & NS & NS & NS & NS \\
\hline $\mathrm{I} \times \mathrm{F}$ & 2 & NS & NS & NS & NS & NS & NS & $* *$ & NS & $*$ & $*$ & NS & NS & NS & NS & NS & NS \\
\hline $\mathrm{I} \times \mathrm{V} \times \mathrm{F}$ & 6 & NS & NS & NS & NS & NS & NS & NS & NS & NS & NS & NS & NS & NS & NS & NS & NS \\
\hline $\mathrm{I} \times \mathrm{S}$ & 2 & NS & NS & NS & NS & NS & NS & NS & NS & NS & $*$ & NS & NS & $*$ & $*$ & NS & NS \\
\hline $\mathrm{I} \times \mathrm{V} \times \mathrm{S}$ & 6 & NS & NS & NS & NS & NS & NS & NS & NS & NS & $*$ & NS & NS & NS & NS & NS & NS \\
\hline $\mathrm{I} \times \mathrm{F} \times \mathrm{S}$ & 2 & NS & NS & NS & $*$ & $*$ & NS & NS & NS & NS & NS & NS & NS & NS & NS & NS & NS \\
\hline $\mathrm{I} \times \mathrm{V} \times \mathrm{S} \times \mathrm{F}$ & 6 & NS & NS & NS & NS & NS & NS & NS & NS & NS & NS & NS & NS & NS & NS & NS & NS \\
\hline Error b & 225 & --- & --- & --- & --- & --- & --- & --- & --- & --- & --- & --- & --- & --- & & & \\
\hline$R^{2}$ & & 0.69 & 0.60 & 0.79 & 0.65 & 0.75 & 0.89 & 0.93 & 0.54 & 0.87 & 0.89 & 0.75 & 0.54 & 0.93 & 0.86 & 0.54 & 0.42 \\
\hline
\end{tabular}

${ }^{\mathrm{z}} 2 \times, 3 \times$, and $4 \times=15 \mathrm{~min}$ of irrigation 2,3 , or 4 times daily. V1, V2, V3, and V4 = container volumes of $98,164,262$, and $530 \mathrm{~cm}^{3}$.

y Transformed with squre root.

NS,**** Nonsignificant or significant at $P<0.05$ or 0.01 , respectively. 
Ropaks, and highest for Osmocote (range: 3 to $5 \mathrm{ppm}$ ) (Fig. 4M). Boron averaged 16 to 19 ppm across treatments (data not shown).

\section{Discussion}

Growth of container-grown plants can be affected by numerous factors including container type and size (Laiche and Newman, 2990; Tilt et al., 1987), substrate (Tilt et al., 1987), fertilizer source and rate (Laiche and Newman, 1990; Neel and Donselman, 1977; Worrall et al., 1987), and irrigation regime (Groves et al., 1998, Tyler et al., 1996). In our study, seedling growth was strongly affected by container volume, fertilizer source, substrate, and irrigation frequency (Table 1, Figs. 2-5), with container volume appearing the most important. Large containers, in addition to providing more rooting volume for water and mineral nutrients, often have a greater air fraction in the substrate (Bilderback and Fonteno, 1987). Normally, the goal is to maximize the number of commercially usable plants per square unit of nursery space. Factors other than plant growth often influence container selection. While larger containers yielded larger plants with more value per plant, the higher cost per seedling (more nursery area, substrate,
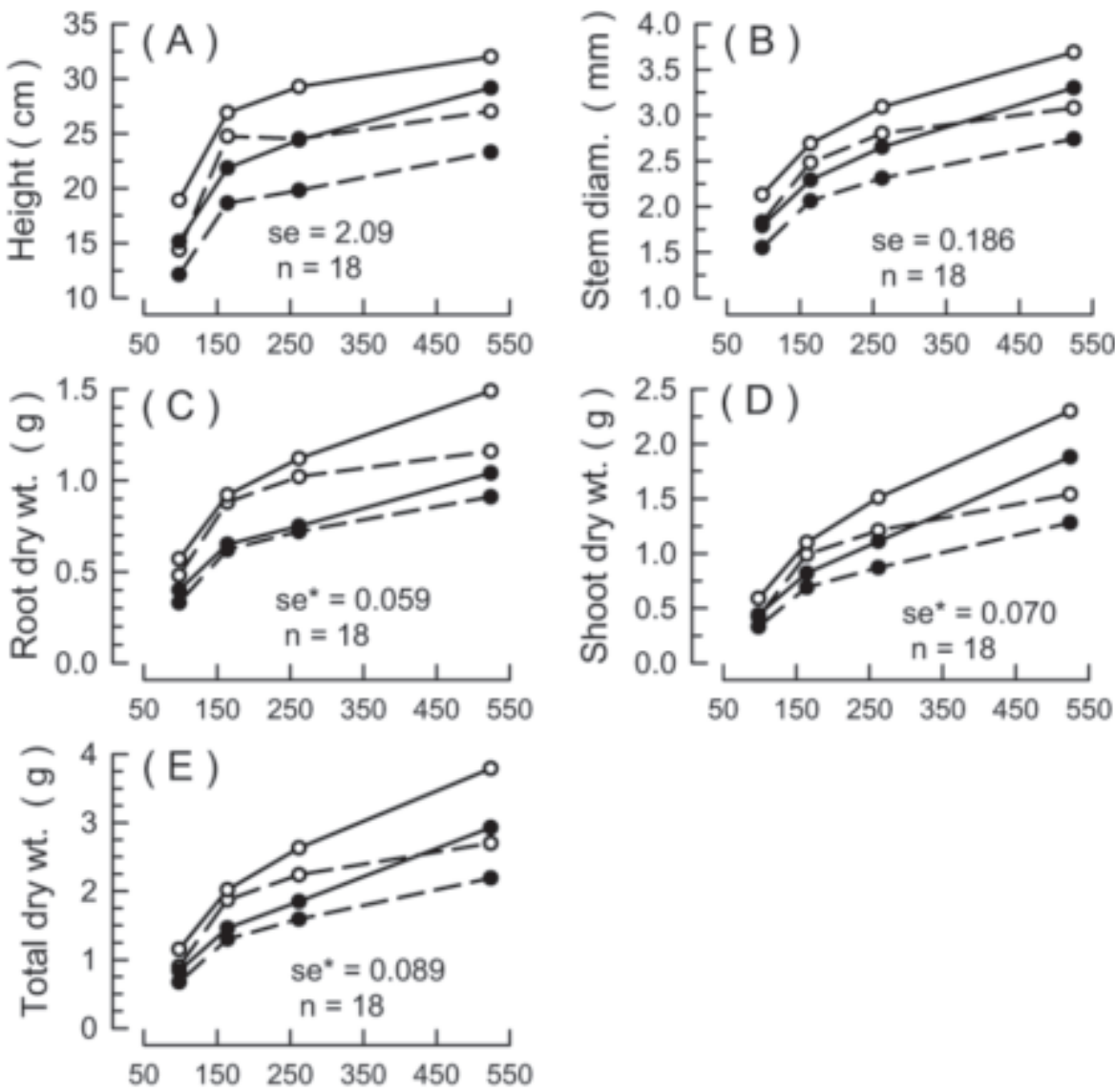

\section{Container volume $\left(\mathrm{cm}^{3}\right)$}

Fig. 2. Growth of atlantic white cedar in response to substrate and fertilizer source when grown in containers of varying volume. (A) Height, (B) stem diameter, (C) root dry weight, (D) shoot dry weight, (E) total dry weight. (O) Polyon, (O) Osmocote, (-----) NCFS substrate, (--- ---) 3 bark : 1 peat substrate. Means are in original units; $\mathrm{SE}=$ standard error of the mean; asterisk indicates the SE after a squareroot transformation; $\mathrm{n}=18$. minor importance, e.g., N, P, and S. Container volume affected most nutrients, e. g., N, P, and especially $\mathrm{Mn}$; and appeared almost equal in importance to fertilizer and substrate (Table 1). As expected, there were several differences related to fertilizer source (Table 1). Based on actual concentrations, as well as relative and absolute differences among treatments, the advantage of Osmocote likely resulted from greater availability of P (Fig. 4E), as noted by Greenwood (1994). Similar results also were observed in a concurrent experiment with AWC that evaluated application rates of CRF (Derby and Hinesley, 2005b). While there are no published normal foliar mineral nutrient levels for Chamaecyparis Spach spp., the foliar $\mathrm{P}$ concentrations for Polyon were very low while Osmocote was near normal, compared to published values for other closely related conifers (Blinn and Bucker, 1989).

Although irrigation frequency (main-plot treatment) affected dry weight as well as concentrations of several mineral nutrients, differences tended to be small relative to the effects of sub-plot treatments (container volume, fertilizer, and substrate) (Table 1, Fig. 4). Plants grown in the NCFS substrate with Osmocote continued to increase in dry weight even at the highest irrigation frequency (Fig. 3); in other treatments, there was no advantage to watering
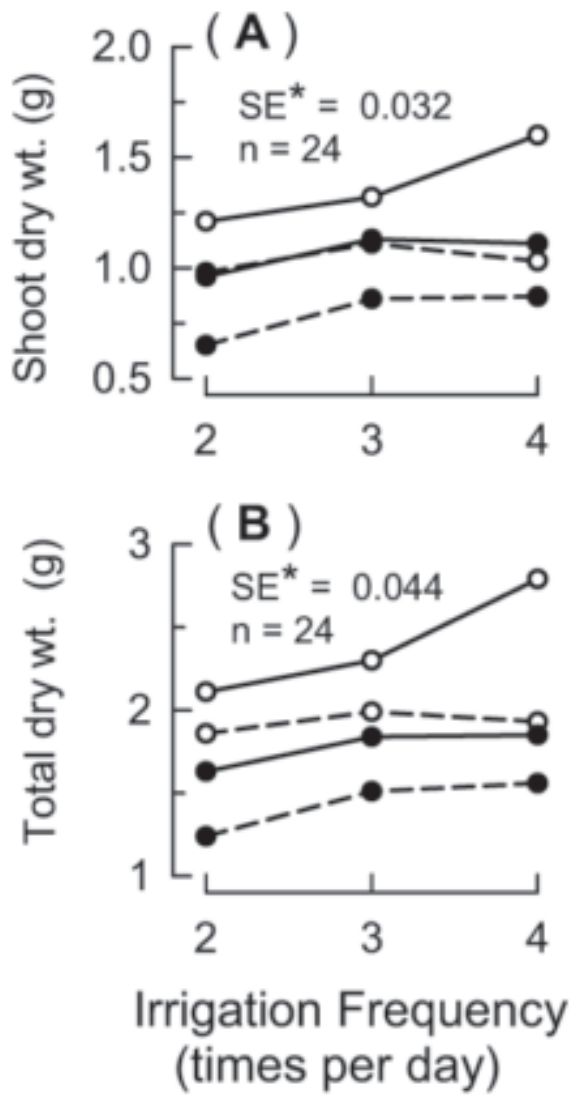

Fig. 3. Dry weight of container-grown atlantic white cedar as affected by substrate, fertilizer source, and irrigation frequency (three-way interaction). (A) Shoot dry weight, (B) Total plant dry weight. (O) Polyon, (O) Osmocote, (----) NCFS substrate, (--- ---) 3 bark : 1 peat substrate. $\mathrm{SE}=$ standard error of the mean; asterisk indicates SE after a square-root transformation; $n=24$. 

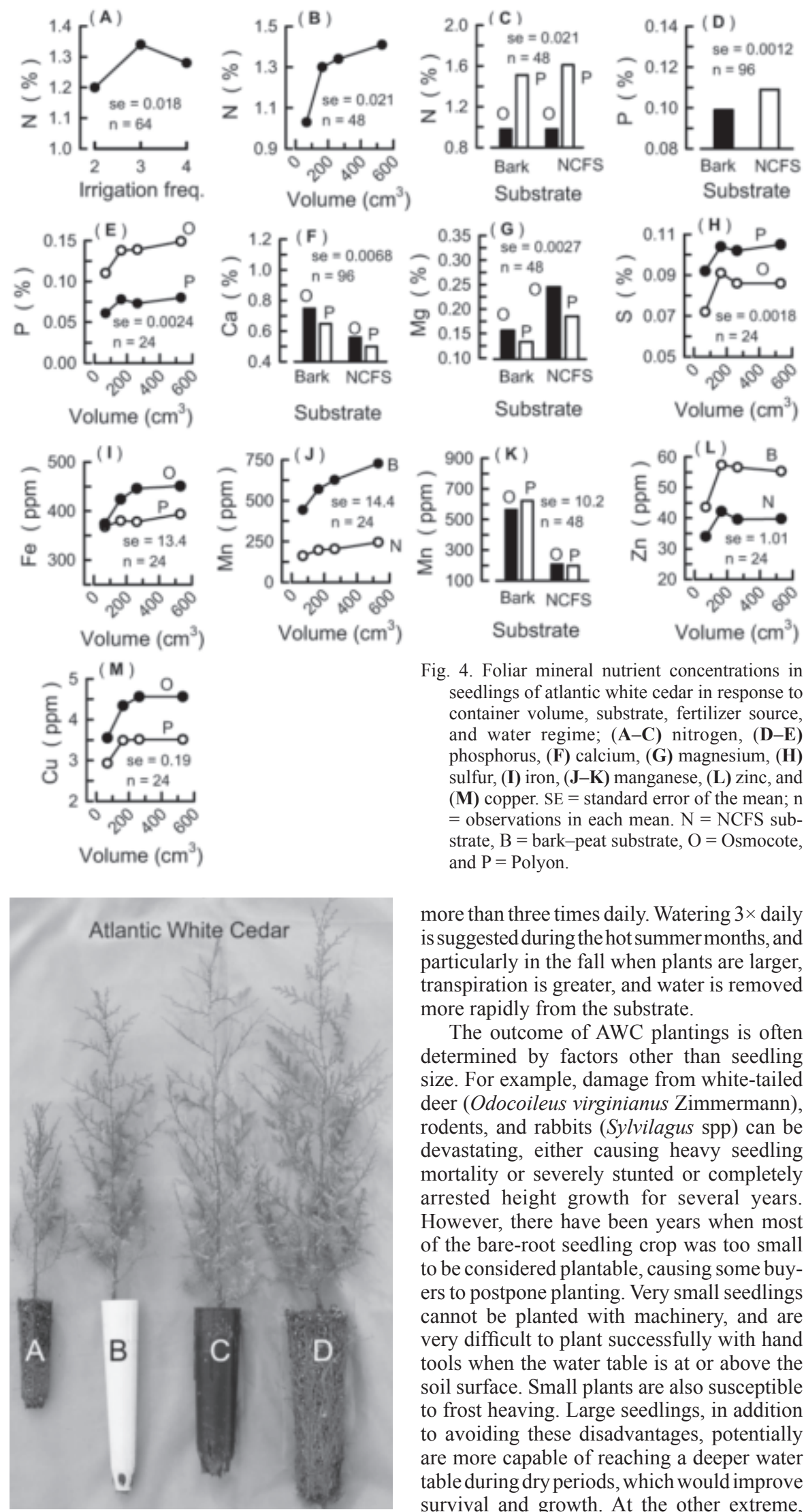

Fig. 5. Seedlings of atlantic white cedar grown for 16 weeks in containers of varying size. (A) Ropak 45 multipot $\left(98 \mathrm{~cm}^{3}\right.$, depth $\left.=12 \mathrm{~cm}\right)$, (B) Ray Leach Super Cell $\left(164 \mathrm{~cm}^{3}\right.$, depth = $21 \mathrm{~cm}),(\mathbf{C})$ Ray Leach Deepot $\left(232 \mathrm{~cm}^{3}\right.$, depth $=18 \mathrm{~cm})$, and (D) Hiko V530 tray $\left(530 \mathrm{~cm}^{3}\right.$, depth $=20 \mathrm{~cm})$.
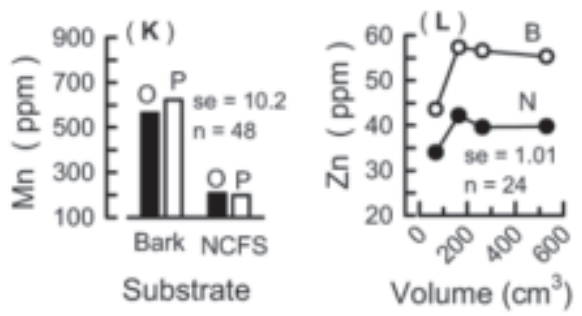

Fig. 4. Foliar mineral nutrient concentrations in seedlings of atlantic white cedar in response to container volume, substrate, fertilizer source, and water regime; (A-C) nitrogen, (D-E) phosphorus, (F) calcium, $(\mathbf{G})$ magnesium, $(\mathbf{H})$ sulfur, (I) iron, (J-K) manganese, (L) zinc, and (M) copper. $\mathrm{SE}=$ standard error of the mean; $\mathrm{n}$ = observations in each mean. $\mathrm{N}=$ NCFS substrate, $\mathrm{B}=$ bark-peat substrate, $\mathrm{O}=$ Osmocote, and $\mathrm{P}=$ Polyon.

more than three times daily. Watering $3 \times$ daily is suggested during the hot summer months, and particularly in the fall when plants are larger, transpiration is greater, and water is removed more rapidly from the substrate.

The outcome of AWC plantings is often determined by factors other than seedling size. For example, damage from white-tailed deer (Odocoileus virginianus Zimmermann), rodents, and rabbits (Sylvilagus spp) can be devastating, either causing heavy seedling mortality or severely stunted or completely arrested height growth for several years. However, there have been years when most of the bare-root seedling crop was too small to be considered plantable, causing some buyers to postpone planting. Very small seedlings cannot be planted with machinery, and are very difficult to plant successfully with hand tools when the water table is at or above the soil surface. Small plants are also susceptible to frost heaving. Large seedlings, in addition to avoiding these disadvantages, potentially are more capable of reaching a deeper water table during dry periods, which would improve survival and growth. At the other extreme, excessively large seedlings are more expensive and difficult to handle during all phases of production and establishment.

Planting stock of adequate size and quality can be reliably produced by suitable manipulation of irrigation frequency, container volume, source and rate of controlled-release fertilizer, substrate, and perhaps other cultural practices as well. A container volume of 160 to $250 \mathrm{~cm}^{3}$ is suggested for production of containerized seedlings in the nursery during the first growing season from seed. Such plants are compatible with traditional planting methods, e.g., dibble bars; and can be efficiently and economically managed during lifting, storing, transporting, carrying, and planting.

\section{Literature Cited}

Ashe, W.W. 1894. The forest, forest lands, and forest products of eastern North Carolina. N.C. Geol. Survey Bul. 5.

Bentz, R. W. and R. D. Iverson. 1992. Atlantic white cedar: Fact, fable, and future? Proc. N.E. Weed Sci. Soc. 46:201-206.

Bianchetti, A., R.C. Kellison, and K.O. Summerville. 1994. Substrate and temperature tests for germination of atlantic white cedar seed (Chamaecyparis thyoides). USDATree Planters' Notes 45(4):125-127.

Bilderback, T.E. and W. C. Fonteno. 1987. Effects of container geometry and media physical properties on air and water volumes in containers. J. Environ. Hort. 5:180-182.

Blinn, C.R. and E.R. Bucker. 1989. Normal foliar nutrient levels in North American forest trees: A summary. Minn. Agr. Expt. Sta. Bul. 59-1989.

Boyle, E. D. and J. E. Kuser. 1994. Propagation of atlantic white-cedar by seed and cuttings in New Jersey. USDA Tree Planters' Notes 45:104-111.

Campbell, C.R. 1992. Determination of total nitrogen in plant tissue by combustion. Plant analysis reference procedures for the Southern Region of the United States. S. Coop. Ser. Bul. 368:21-23.

Campbell, C.R. and C.O. Plank. 1992. Sample preparation. Plant analysis reference procedures for the Southern Region of the United States. S. Coop. Ser. Bul. 338:8-9.

Davis, K.N., B. Henderson, and S. Daniels. 1997. Inventory of atlantic white cedar remnant stands in North Carolina. U.S. Air Force BPA No. F31610-95-AV026.

Derby, S.A. and L.E. Hinesley. 2005a. Water table and temperature regime affect growth of potted atlantic white cedar. In: M.K. Burke and P. Sheridan (eds.). Atlantic white cedar: Ecology, restoration, and management. Proc. Arlington Echo Symp., 2-4 June 2003. USDA For. Serv. S. Res. Sta., Gen. Tech. Rpt. SRS (in press).

Derby, S.A. and L.E. Hinesley. 2005b. Fertilizing containerized atlantic white cedar seedlings. J. Environ. Hort. 23:97-100.

Dirr, M.A. 1990. Manual of woody landscape plants: Their identification, ornamental characteristics, culture, propagation, and uses. 4th ed. Stipes Publ. Co., Champaign, Ill.

Frost, C.C. 1987. Historical overview of atlantic white cedar in the Carolinas, p. 257-264. In: A.D. Laderman (ed.). Atlantic white cedar wetlands. Westview Press, Boulder, Colo.

Greenwood, L.L. 1994. Greenhouse production of atlantic white cedar seedlings. MS thesis. N.C. State Univ., Raleigh.

Groves, K.M., S.L. Warren, and T.E. Bilderback. 1998. Irrigation volume, application, and controlled-release fertilizers: I. Effect on plant growth and mineral nutrient content in containerized plant production. J. Environ. Hort. $16: 176-181$

Hinesley, L.E. and L.K. Snelling. 1997. Rooting stem cuttings of atlantic white cedar outdoors in containers. HortScience 32:315-317.

Hinesley, L.E. and A.M. Wicker. 2003. Research at 
N.C. State University related to regeneration of atlantic white cedar and baldcypress. U.S. Fish Wildlife Serv. http://nc_es.fws.gov/coastal/plnwrawc/awcindex.html.

Korstian, C.F. and W.D. Brush. 1931. Southern white cedar. USDA For. Serv. Tech. Bul. 251.

Krinbill, H.R. 1956. Southern white cedar: The forgotten tree. S. Lumber J. 60(11):26, 28, 36, 45

Kuser, J.E. and G.L. Zimmermann. 1995. Restoring atlantic white-cedar swamps: Techniques for propagation and establishment. USDA Tree Planters' Notes 46 (3):78-85.

Laderman, A.D. 1989. The ecology of atlantic white cedar wetlands: A community profile.U.S. Dept. Interior, Fish and Wildlife Serv. Res. and Dev., Natl. Wetlands Res. Ctr., Biol. Rpt. 85(7.21).

Laiche, A.J. and S.E. Newman. 1990. Effects of container size and fertilizer rate on growth of Rhododendron 'Formosa' and Ilex 'Nellie R. Stevens' plants. Proc. Intl. Plant Prop. Soc. 39:354-360.
Lilly, J.P. 1981. Ahistory of swampland development in North Carolina. p. 20-39. In: C.J. Richardson (ed.). Pocosin wetlands: An integrated analysis of Coastal Plain freshwater bogs in North Carolina. Hutchinson Ross, Stroudsburg, Pa.

Neel, P.L. and H.M. Donselman. 1977. Growth of five species of containerized ornamentals as influenced by six commercial [slow-release] fertilizer sources. Proc. Fla. State Hort. Soc. 90:350-353.

Phillips, R.W., J.H. Hughes, M.A. Buford, W.E. Gardner, F.M. White, and C.G. Williams. 1998. Atlantic white cedar in North Carolina, USA: A brief history and current regeneration efforts, p. 156-170. In: A.D. Laderman (ed.). Coastally restricted forests. Oxford Univ. Press, New York.

SAS Institute, Inc. 1990. SAS/STAT user's guide: Statistics. version 6. SAS Inst. Inc., Cary, N.C. Summerville, K.O., W.E. Gardner, and L.E. Hinesley. 1999. Atlantic white cedar plant production, $\mathrm{p}$
68-75. In: T. Shear and K.O. Summerville(eds.). Proc. atlantic white cedar: ecol. and mgt. symp., 6-7 Aug. 1997. Christopher Newport Univ., Newport News, Va. USDA For. Serv. S. Res. Sta. Gen. Tech. Rpt. SRS-27.

Tilt, K.M., T.E. Bilderback, and W.C. Fonteno. 1987. Particle-size and container size effects on growth of 3 ornamental species. J. Amer. Soc. Hort. Sci. 112:981-984.

Tyler, H.H., S.L. Warren, and T.E. Bilderback. 1996. Reduced leaching fractions improve irrigation use efficiency and nutrient efficacy. J. Environ. Hort. 14:199-204.

Ward, D. 1989. Commercial utilization of atlantic white cedar (Chamaecyparis thyoides, Cupressaceae). Econ. Bot. 43:386-415.

Worrall, R.J., G.P. Lamont, M.A. O'Connell, and P.J. Nicholls. 1987. The growth response of container-grown woody ornamentals to controlled release fertilizers. Scientia Hort. 32:275-286. 